\title{
Setting the Stage: The Late Pleistocene Colonization of North America
}

\author{
Michael J. O'Brien
}

Department of Arts and Humanities, Texas A\&M University—San Antonio, San Antonio, TX 78224, USA; mike.obrien@tamusa.edu

Academic Editors: Bronwen Whitney, Encarni Montoya and Valentí Rull

Received: 25 August 2018; Accepted: 26 November 2018; Published: 21 December 2018

check for updates

\begin{abstract}
The timing of human entrance into North America has been a topic of debate that dates back to the late 19th century. Central to the modern discussion is not whether late Pleistocene-age populations were present on the continent, but the timing of their arrival. Key to the debate is the age of tools-bone rods, large prismatic stone blades, and bifacially chipped and fluted stone weapon tips-often found associated with the remains of late Pleistocene fauna. For decades, it was assumed that this techno-complex-termed "Clovis" - was left by the first humans in North America, who, by 11,000-12,000 years ago, made their way eastward across the Bering Land Bridge, or Beringia, and then turned south through a corridor that ran between the Cordilleran and Laurentide ice sheets, which blanketed the northern half of the continent. That scenario has been challenged by more-recent archaeological and archaeogenetic data that suggest populations entered North America as much as 15,300-14,300 years ago and moved south along the Pacific Coast and /or through the ice-free corridor, which apparently was open several thousand years earlier than initially thought. Evidence indicates that Clovis might date as early as 13,400 years ago, which means that it was not the first technology in North America. Given the lack of fluted projectile points in the Old World, it appears certain that the Clovis techno-complex, or at least major components of it, emerged in the New World.
\end{abstract}

Keywords: Clovis; drift; Folsom; late Pleistocene; learning; selection; transmission

\section{Introduction}

The exact timing of the colonization of North America is open to question (see below), but what is not in question is the point of origin of the early colonists. Despite a few claims to the contrary, including one that envisions the colonization of North America by Upper Paleolithic people from western Europe some 20,000-24,000 years ago [1], overwhelming archaeological and archaeogenetic evidence [2-16] indicates that humans moved eastward across the Bering Land Bridge, or Beringia, during the Late Glacial Maximum and made their way either south along or near the coast [17-20] and/or through a corridor that ran between the Cordilleran and Laurentide ice sheets that covered the northern half of the continent [21-25]. Both scenarios remain equally viable [24], despite claims to the contrary [17].

With respect to timing, colonizing populations could have entered North America before 16,000 years ago, but the earliest unequivocal and widespread human occupation of the continent dates to around 13,400 years ago [25], the visible manifestation of which is a tool kit referred to as the "Clovis techno-complex" [26]. The dispersal of that techno-complex is exceptional in human-migration research because it occurred over such a short time (see below), which means that, as researchers, we benefit from a temporal resolution not usually available for other instances of colonization [27]. The dispersal of Clovis also allows us to examine at a fine scale how colonization processes can play out across a vast extent of space that at the time had at best a very small resident population. To set the stage for the other papers in this special issue of Quaternary, I focus on the origin and spread of that 
complex, together with the various modes involved in its transmission. Along the way, I examine how various evolutionary processes and mechanisms helped shape what we see in the Clovis archaeological record. Excellent summaries of Clovis lifeways and numerous related topics not included here can be found in [28-35].

\section{The Clovis Techno-Complex}

The Clovis techno-complex is marked by a number of distinctive tool types, including bone and ivory rods [36], large prismatic stone blades [26], and bifacially chipped and fluted stone weapon tips, referred to as "Clovis points" [26,37-40]. Because of significant regional variation in the toolkit, Eren and Buchanan [41], (p. 1) make the excellent point that what archaeologists refer to as "Clovis technology" is better thought of as a shorthand reference to "a fuzzy set of human-tool interactions found across North and Central America during the terminal Pleistocene".

Prehistoric projectile-weapon systems were made from a variety of raw materials, including wood, resins, bone, and fibers, but these materials do not preserve well, and as a result, archaeologists focus on the component that does survive, the flaked-stone projectile point [42]. Clovis points were made from several cryptocrystalline stone types, such as chert, quartzite, and obsidian. They were bifacially flaked (flaked on both sides) and are lanceolate in form. They have parallel to slightly convex sides and concave bases and exhibit a series of flake-removal scars- "flutes" - on one or both faces that extend from the base to about a third of the way to the tip (Figure 1). After fluted points were first recognized archaeologically, it was proposed that fluting enhanced bloodletting of a wounded animal [43], although the flute would have been largely covered by the hafting (e.g., sinew) [44]. Similarly, it was proposed that fluting enhanced hafting a point into a split shaft [45]. Experimentation suggests, however, that the thinner base that results from fluting acts as a "shock absorber" that increases point robustness and the ability to withstand physical stress through stress redistribution and damage relocation $[46,47]$.

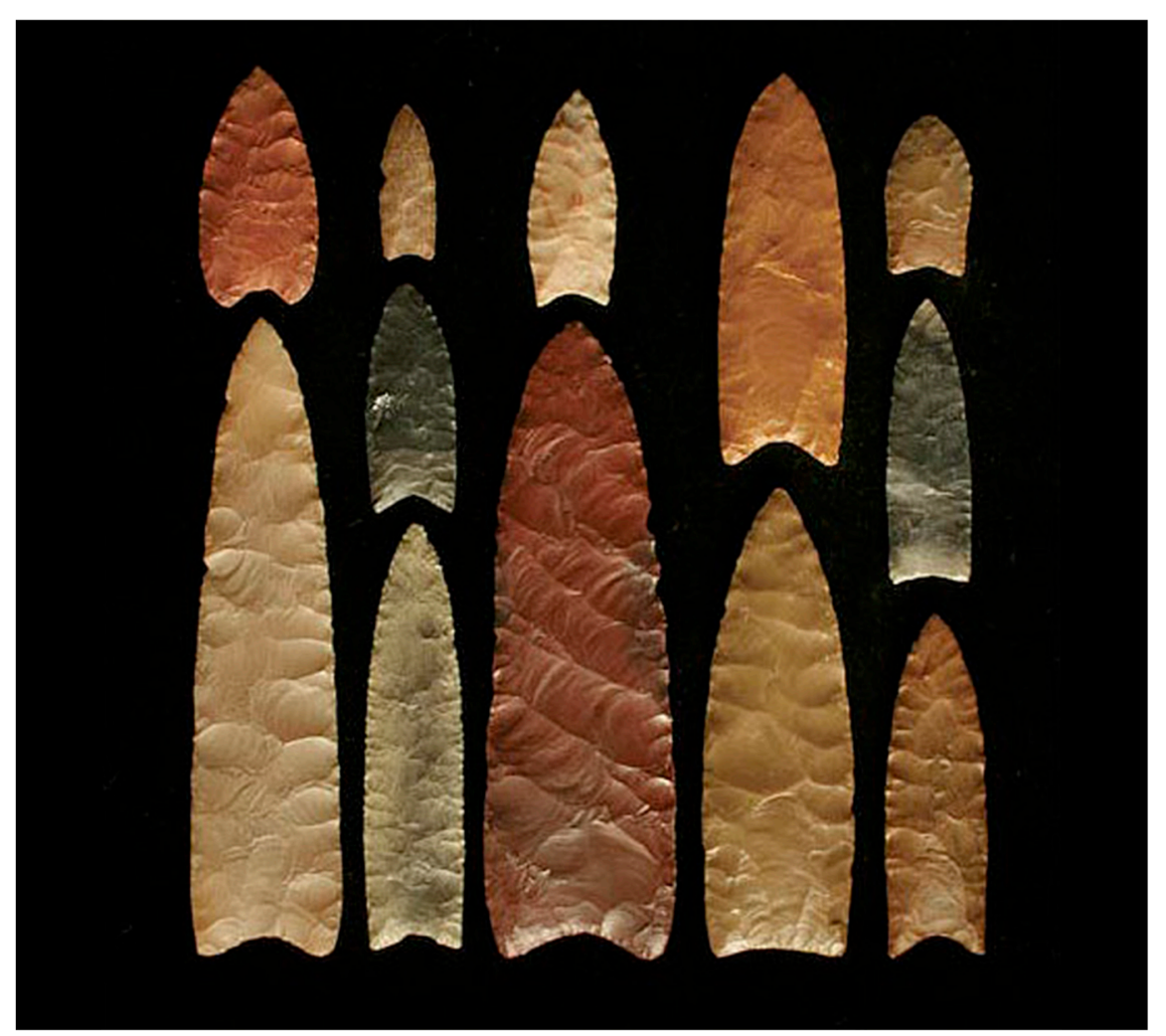

Figure 1. Clovis points from various North American sites. Photo by Charlotte D. Pevny; courtesy Michael R. Waters. 
Microwear analysis shows that at least some Clovis points were used to tip spears that were thrust and/or thrown [48]. Exceedingly large specimens could have functioned as saws, which were held in place by bone or ivory rods acting as levers to tighten sinew lashings [49]. The basal edges of Clovis points, where they were attached to socketed foreshafts or lashed to handles or spears, were ground dull. It has long been presumed that the grinding was done to prevent cutting of the lashings that bind the points in place $[40,45]$, but recent experimental work has shown that there is virtually no damage to lashings, regardless of whether a point has ground or sharp edges [42].

The antiquity of these iconic points was first documented in the American Southwest at Blackwater Draw, New Mexico [50,51], where they were found in association with the remains of extinct animals, such as mammoths, camelids, sloths, and large bison, that were known to be Pleistocene in age. This discovery, alongside one made a few years earlier near Folsom, New Mexico [52], laid to rest a long-standing debate in archaeology over the presence of glacial-age humans in North America [53,54]. Since those early discoveries, Clovis points have been found throughout the contiguous United States, Alaska, southern Canada, and northern Mexico [16,30,40,55-64].

Although not a settled issue, Clovis points appear to have originated in the American Southwest or perhaps Texas [33,65-68] and spread north and east from there. In eastern North America, with a few exceptions, the earliest dates from archaeological sites that have produced large numbers of fluted points consistently fall later in time than the earliest fluted points in the West [69-75]. To simplify a rather complex chronology, we can assign a range of 13,400-12,800 years ago for Clovis in the western half of the continent, after which Clovis points were replaced by Folsom points. Although similar to Clovis points, Folsom points are smaller, have longer and deeper flutes, and were made using only biface reduction instead of both biface and flake reduction [37,40,76,77] (Figure 2). Folsom points date to ca. 12,800-11,900 years ago and have little chronological overlap with Clovis. The earliest Folsom points occur in the Northern Plains and the younger ones in the Southern Plains and eastward toward the Mississippi River [59,78-82].

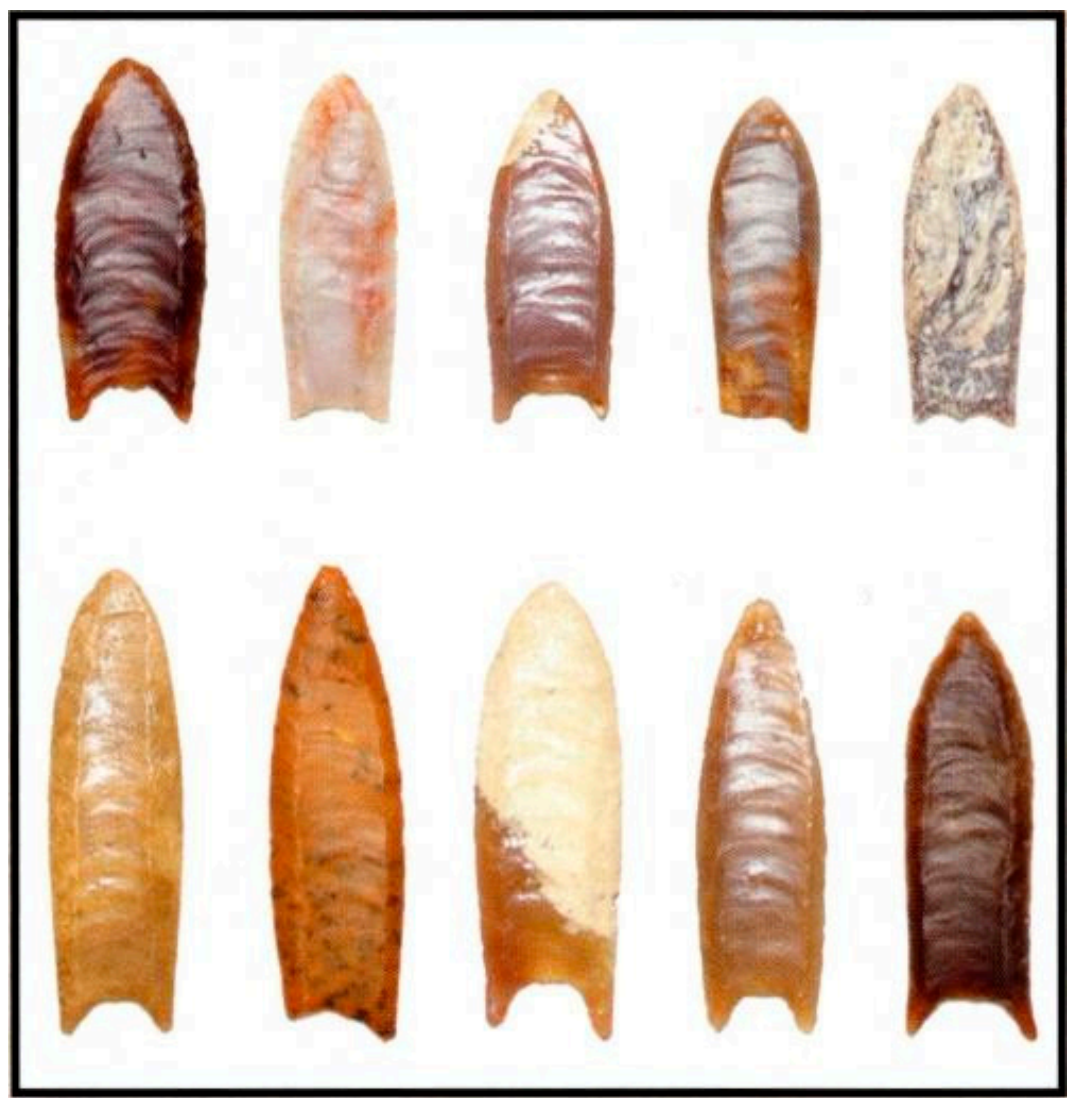

Figure 2. Folsom points from various North American sites. Photo courtesy Jeb Taylor. 
The transition from Clovis to Folsom was a significant event in the prehistory of western North America, driven, at least in part, by population expansion, perhaps in response to climate-driven environmental change. The transition involved shifts in hunting practices and land use, with available evidence suggesting that in contrast to Clovis hunters, who exploited a wide range of game, including mammoth, mastodon, bison, and caribou [83-87], Folsom hunters specialized in hunting bison [88-95]. This difference may have resulted from the extinction of the majority of North American megafaunal species at the end of the Pleistocene [34,96,97]. Folsom toolkits were more diverse than their Clovis counterparts, commonly including large numbers of formal end scrapers [98] and occasionally ultrathin bifaces $[99,100]$.

The chronological issue is even more complicated in the East as a result of the way the term "Clovis point" is defined [16,64,101-104]. As opposed to in the West, there are a number of fluted forms in the East that some researchers identify as Clovis and others that they place in types such as Gainey or Bull Brook (Figure 3). As a group, the points date ca. 12,800-12,200 years ago, decidedly later than in the West $[105,106]$, which is not unreasonable, given that fluting apparently began in the West and moved eastward (but see [107]), either through the movement of populations or through down-the-line transmission among established populations (see Section 5). Those eastern forms were followed by other fluted forms [69,75,107-119] (Figure 3) that persisted up to 12,000-11,800 years ago, placing them in the same chronological range as Folsom $[105,106]$.
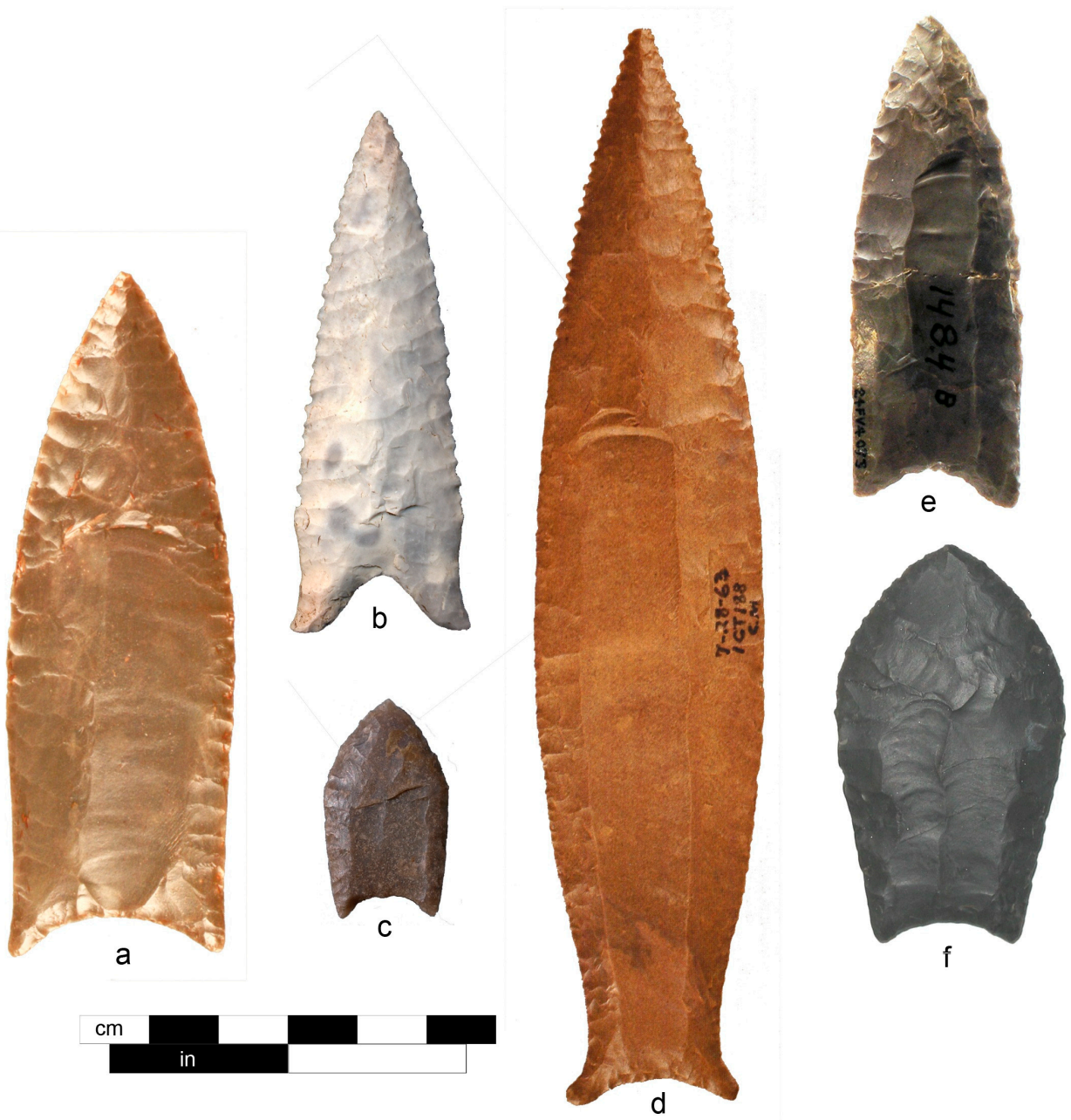

Figure 3. Examples of Paleoindian fluted projectile points from eastern North America and a Folsom point from western North America: (a) Clovis; (b) Dalton; (c) Folsom; (d) Cumberland; (e) Gainey/Bull Brook; (f) Crowfield. Reproduced with permission from [102]; figure by Matthew Boulanger. 


\section{Earlier Techno-Complexes}

As widespread as components of the Clovis tool kit are, they apparently were not the first technological items to appear in North America. Here, I focus on three sites-Page-Ladson, Gault, and Debra L. Friedkin - that have produced reliable radiocarbon or optically stimulated thermoluminescence (OSL) ages in direct association with stone tools and by-products of tool manufacture.

Page-Ladson, located in a sinkhole in Florida's Aucilla River [120], contained a few biface fragments and other pieces of stone in close association with the remains of mastodon, bison, and camelids [121]. The most significant stone tool was a small reworked knife fragment, which, based on seven radiocarbon samples collected immediately adjacent to it, dates to ca. 14,550 years ago, predating even the earliest Clovis dates in the western United States by over a thousand years. To confirm the age of the biface and to test that it was in an undisturbed context, a vertical series of 24 radiocarbon samples was taken from $1.1 \mathrm{~m}$ above to $0.6 \mathrm{~m}$ below the biface. The sequence of almost identical radiocarbon ages indicates that the tool was lying in undisturbed sediments.

Debra L. Friedkin is located in the floodplain of the Buttermilk Creek valley of central Texas, near a source of reliable water and high-quality chert [68] (Figure 4). Several cultural horizons are present at the site and are in correct stratigraphic order. The Clovis horizon is a 2.5 -cm-thick layer of overbank sediment in which tools and by-products of manufacture and use were found, including three bifaces with overshot flake-removal scars, three channel flakes, and five blade segments. Overshot flaking is a method of thinning a bifacially flaked tool during manufacture, in which flakes struck from prepared edges of the tool travel across the face and remove part of the opposite margin. Experimental data demonstrate that the most parsimonious explanation for the production of overshot flakes is that they are accidental products created incidentally and inconsistently as knappers' attempts to thin bifaces [122]. Accidents or not, overshot flakes show up in Clovis assemblages, albeit in relatively low frequencies, and are often used to mark an assemblage as being Clovis in age. Below the Clovis horizon at Debra L. Friedkin is a 20-cm-thick layer containing stone tools and by-products of manufacture that represent repeated visits to the site and together define the "Buttermilk Creek Complex" (Figure 5). Eighteen OSL ages in the range of 17,500-14,000 years ago were obtained from the layer, all but three of which overlap at one standard deviation. As a conservative estimate, Waters et al. [68] place the age of the Buttermilk Creek Complex as ca. 15,500-13,200 years ago (see [123] for a conflicting opinion on dates and context; see $[124,125]$ for rebuttals).

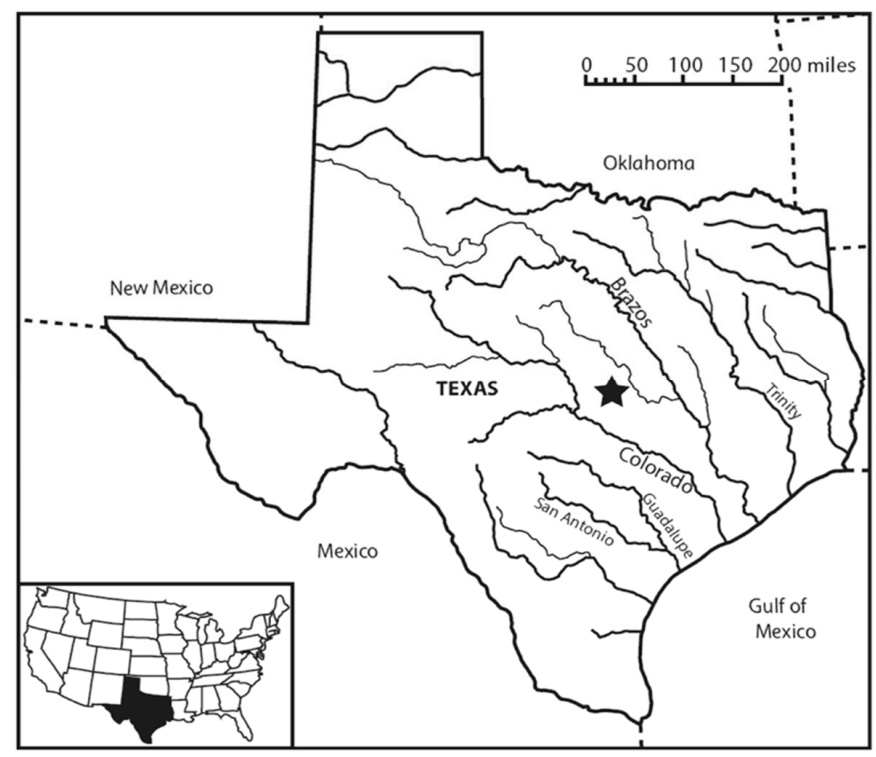

Figure 4. Location of the Gault site and the Debra L. Friedkin site in central Texas. Reproduced from [126]; courtesy Michael B. Collins. 


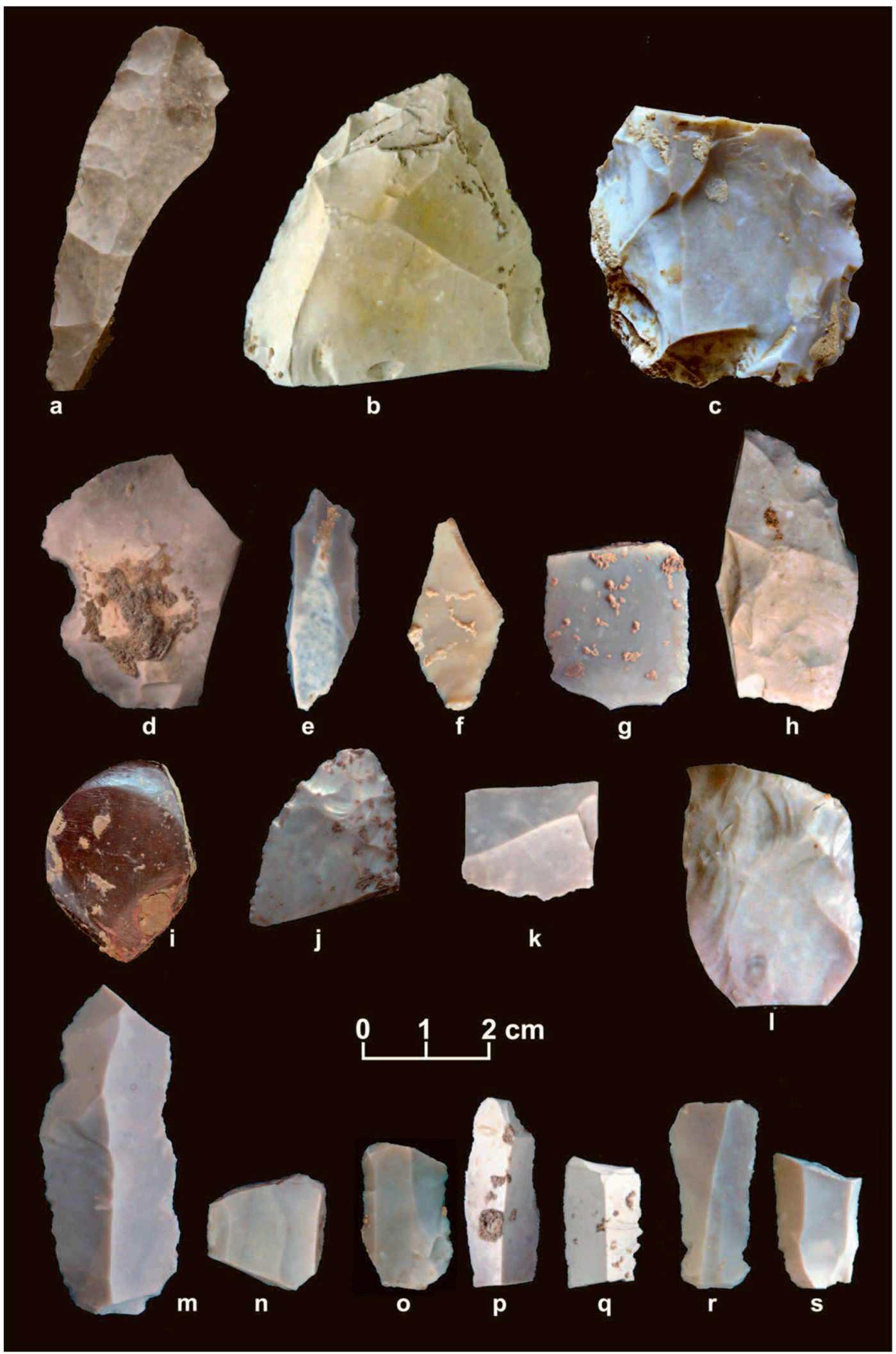

Figure 5. Buttermilk Creek Complex artifacts: (a) Lanceolate point preform; (b) chopper/adze; (c) discoidal flake core; (d) radially broken flake with notch; (e) graver; (f) flake tool with retouch on a radially broken edge; $(\mathbf{g}, \mathbf{h})$ flake tools with marginal edge retouch; (i) polished hematite; (j) bifacially retouched flake; (k) radially/bend broken flake; (1) radially broken biface; $(\mathbf{m}, \mathbf{n})$ blade midsections; (o-s), bladelets. Reproduced with permission from [68]; courtesy Michael R. Waters. 
Gault (Figure 4) is located approximately $250 \mathrm{~m}$ upstream from Debra L. Friedkin. It too contains well-stratified deposits, including a 25-cm-thick Clovis component, which is underlain by a 65-80-cm-thick deposit of silty clay and fluvial gravel deposits that contains the "Gault Assemblage" [126] (Figure 6). The assemblage exhibits the technology for producing small stemmed or lanceolate projectile points as well as both a biface and a blade-and-core tradition. Large and small blades and tools made on blades are similar to, yet distinct from, Clovis tools. Bifaces are also similar in form to Clovis bifaces-specimens X and Y in Figure 6, for example-but are smaller and technologically distinctive [126]. OSL dates place the minimum age of the Gault Assemblage (two standard deviations) at ca. 24,500-14,500 years ago, although the range in dates suggests that the site could have been inhabited one or two thousand years earlier.

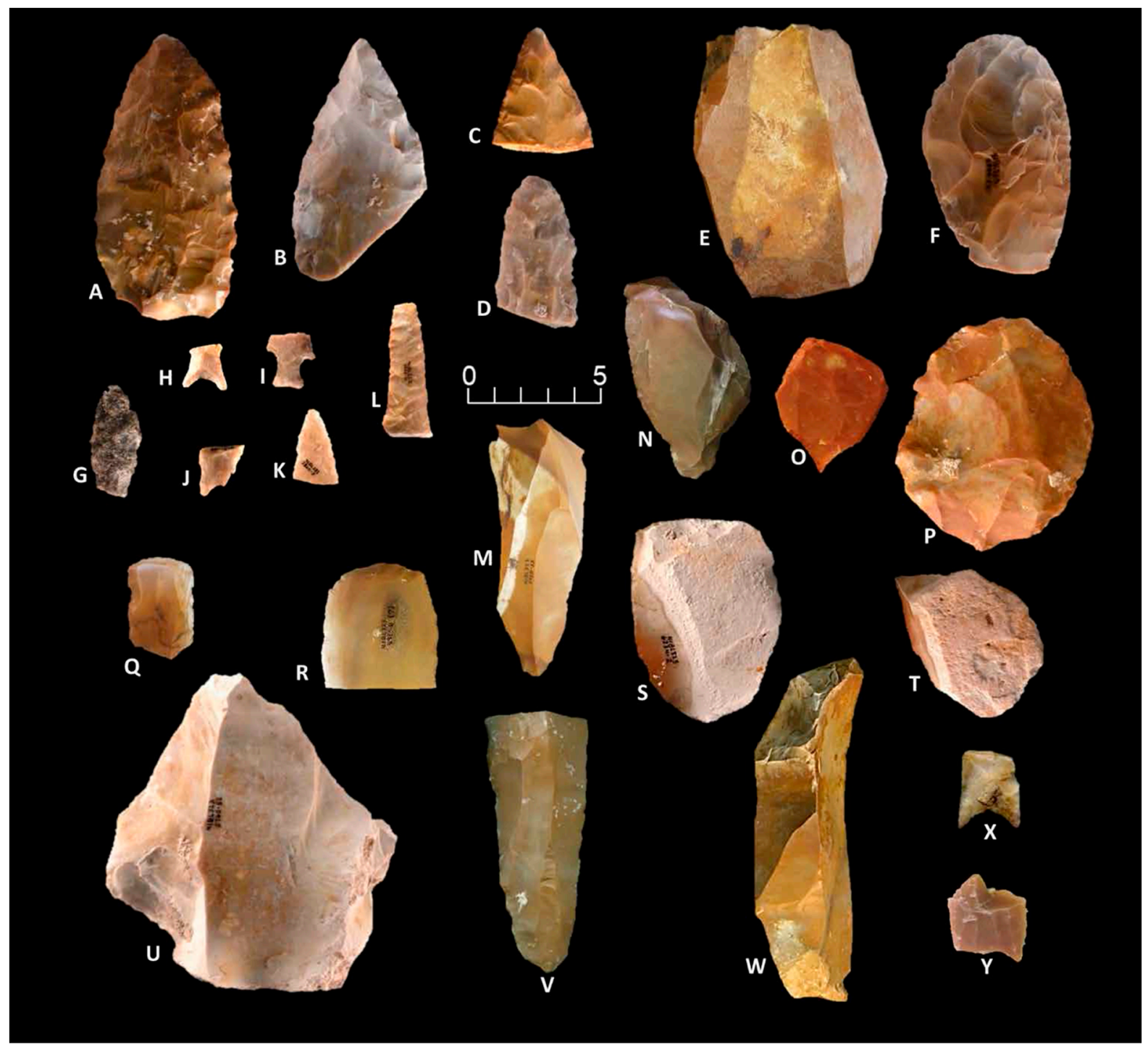

Figure 6. Gault Assemblage artifacts: (A-D,F,L) bifaces; (E) blade core; (G) quartz projectile point; $(\mathbf{H}-\mathbf{J})$ projectile points; (K) projectile-point tip; $(\mathbf{M}, \mathbf{V}, \mathbf{W})$ blades; $(\mathbf{N})$ unifacial tool; $(\mathbf{O}, \mathbf{T})$ gravers; (P) discoidal biface; $(\mathbf{Q})$ end scraper; $(\mathbf{R}-\mathbf{U})$ modified-flake tools; $(\mathbf{X}, \mathbf{Y})$ lanceolate projectile points (units in cm). Reproduced from [126]; courtesy Michael B. Collins.

\section{Can We Find Clovis Progenitors?}

For years, archaeologists assumed that much, if not all, of the Clovis technology was carried eastward across Beringia, and they combed the archaeological records of both Siberia and North 
America to find ties between Clovis and the Upper Paleolithic of northeastern Asia [127]. Results have been mixed at best, with no clear candidates [128-133]. Aspects of eastern Beringian tool kits, including retouched blades and end scrapers, show up in Clovis assemblages, but microblades and microcores, which dominate eastern Beringian tool kits [134], do not [127]. This situation, where there are similarities and differences, should not be unexpected, given that it seems unreasonable to assume that colonizing groups suddenly abandoned their entire technology and created a new one. Rather, we should expect significant overlap for some period of time. As a side note, the focus that American archaeologists have had on fluting has tended to obscure the fact that other technological aspects of stone-tool assemblages-Siberian, Beringian, and Clovis-have been overlooked, including the above-mentioned continuity in blade and end-scraper manufacture.

What about similarities between Clovis and earlier technologies in North America south of the Pleistocene ice sheets? Can we identify Clovis progenitors? Page-Ladson, the Gault Assemblage, and the Buttermilk Creek Complex date earlier than the commonly accepted dates for Clovis, but what, if any, is their evolutionary relationship to Clovis? Are they progenitors of Clovis, or could they, in fact, be very early Clovis assemblages that lack fluted points, either because of sampling error or the fact that fluting had not yet been invented? It seems highly unlikely that the small sample of radiocarbon dates for the Clovis period has captured the earliest or latest use of Clovis points $[135,136]$ in either half of the continent, which is not surprising, as the general expectation in archaeology and palaeontology is that most first-appearance dates are underestimates [102]. Taphonomic processes are such that the probability of a given first-appearance date being too young is high [136]. Thus, the case could be made that the Buttermilk Creek Complex is a very early manifestation of Clovis.

Prior to the reporting of the pre-Clovis Gault Assemblage in 2018, Jennings and Waters [137] compared technological and typological traits from Clovis-age material from Debra L. Friedkin and Gault to traits in the Buttermilk Creek Complex at Debra L. Friedkin. The two Clovis assemblages are significantly different from one another in a number of respects, including frequencies of large debitage and overshot flakes and relative counts of debitage types. Similarly, the Buttermilk Creek Complex differs from both Clovis assemblages in that it lacks fluted points, bifaces with overshot flaking, blade cores, and retouched blades. Conversely, it resembles Clovis in terms of six of 10 characteristics that Jennings and Waters identified as often used to define Clovis. In general terms, Clovis and Buttermilk Creek Complex tool makers both used bifacial reduction, manufactured blades and bladelets, and reduced discoidal cores (Figure 6). Similarly, both produced a number of tool forms, including bifacially flaked points and chopping tools. In addition, the size of Clovis blades and bladelets (not to be confused with arctic microblades [134]) overlapped with those from the Buttermilk Creek Complex, which suggests similar reduction goals [137].

In terms of assemblage similarities and differences, Haynes [137] notes that the differences might mean that the Buttermilk Creek Complex is not a variant of Clovis, but, conversely, perhaps the similarities mean that it is technologically related to Clovis, perhaps a direct ancestor that lacks fluting. Similarities between the pre-Clovis Gault Assemblage and the Buttermilk Creek Complex suggest that they might both be ancestral to Clovis. With respect to the Buttermilk Creek Complex, Waters et al. [68], (p. 1601) think a good case can be made that it is ancestral to Clovis: "The Buttermilk Creek Complex tool kit-bifaces made through core reduction including end thinning, a lanceolate-like preform, a discoidal core, blades, bladelets, radially broken tools, a variety of edge-modified tools (notches, gravers, and scrapers), and ground hematite-also provides an ancestral assemblage from which the biface- and blade-dominated Clovis tool kit could have evolved." In any case, in assessing similarities and differences between the two assemblages, we need to keep in mind the considerable difference in OSL age ranges for the two, with the Gault Assemblage apparently being considerably older than the Buttermilk Creek Complex.

Of considerable importance is the fact that archaeogenetic data support the possible presence of a pre-Clovis population in the interior of North America-or, more precisely, a population that is older than the commonly used dates for Clovis. I noted earlier that archaeogenetic data supported the origins 
of North American populations as being in eastern Beringia as opposed to western Europe $[9,11,12,14]$, but it was the analysis of a male infant from the Anzick site in Montana that provided some of the most important information [15]. The remains of the infant date ca. 12,700-12,600 years ago and were recovered with Clovis tools. Genome sequencing showed that the gene flow from a Siberian Upper Paleolithic population [13] into ancestors of Native Americans was also shared with the Anzick 1 infant. In other words, the infant belonged to a population directly ancestral to contemporary Native Americans. There also was clear evidence of a deep divergence in North American populations that predated the Anzick infant, perhaps by as much as several thousand years.

\section{The Elusive Origins of Fluting}

Fluted points occur in the Alaskan Arctic, alongside a number of nonfluted forms, but it is becoming clear that fluting technology arrived in the Arctic from the south, carried by established populations moving northward through the ice-free corridor [63]. Thus, it appears that any early signs of fluting will come from temperate North America, but to date, it has not been recognized as such (but see below). With respect to pre-Clovis projectile points, the Gault Assemblage, as we saw, comprises both small stemmed and lanceolate projectile points, but neither it nor the Buttermilk Creek Complex contains evidence of fluting, in terms of either finished pieces or by-products of the fluting process.

The lack of a clear Clovis-point progenitor suggests that fluting in its full or near-full form (see below) appeared suddenly on the Southern Plains $[16,64]$. In evolutionary terms, fluting was an adaptation, defined as a trait that is under selection. In everyday terms, selection is used as a synonym for choice, but in biology and the behavioral sciences, the term refers to the differential survival and reproduction of individuals within a population that results from phenotypic differences among them. We can also move down a level and examine the effects selection has on the rise and decline of specific phenotypic traits. This examination is based on the proposition that items in the archaeological record are parts of human phenotypes in the same way that skin and bones are, and as such they are capable of yielding data relevant to understanding both the process of evolution and the specific evolutionary histories of the individuals who possess the traits [138].

Often misunderstood is the fact that selection is a creative process and not a negative force, meaning that it constantly reshapes the pool of available variants by recombining traits and by turning inventions - the cultural equivalents of mutations-into innovations. Traits that affect fitness-those under selection-are termed functional traits. Some functional traits will grow slowly in a population and then decline as they are replaced by competitors, whereas others will display discontinuous, multimodal frequency distributions as a result of convergence. In the latter case, unrelated groups find similar solutions to similar problems-they "converge" on the same peak on a fitness landscape [139]. The archaeological record is rife with examples of convergence-Clovis points and Paleolithic Solutrean points from western Europe, for example [140]. Still other functional traits will display an S-shaped curve that has a small left-hand tail, followed by a steep upward turn that reflects an exponential growth in popularity, and then a leveling off as the trait saturates the population, as fluting did over much of North America.

With respect to complex technological systems (CTSs) —and Clovis points fall in that categorytwo highly interrelated processes can play important roles in the trajectories of functional traits [141]. One is stimulated variation [142], defined as an increase in invention resulting from changing selective conditions-literally a "burst of variation." The other is cascading [143], defined as sequential spurts of invention that occur through the recognition of emergent performance problems in a CTS. Here, perceived deficiencies create a rapid pile-up of new variants resulting from attempts to overcome the deficiencies. In other words, cultural traits realign into new recipes [144] and replace less-efficient variants.

In evolutionary terms, variants that have the potential of taking on new, unrelated functions-as feathers did in birds-are called exaptations [145]. With respect to fluting, can we find evidence of manufacturing stages that were exaptations—-stages that, with a little more development, turned into 
fluting? Often, the intensification of a function is all that is required for a structure to be able to take on a new function. The crucial factor in the acquisition of most evolutionary novelties is a shift in behavior [146], coupled with, especially in the case of humans, "attentive observation and practical, daily application" [46], (p. 2). Perhaps incipient basal thinning, undertaken to reduce the longitudinal thickness of a biface - what Bradley [110] refers to technological fluting — underwent a significant series of changes in structural function, equivalent to Schiffer's [142] "stimulated variation." Eventually, it came under strong selection, which then led to full bifacial fluting-Bradley's [110] morphological fluting—a case of Schiffer's [143] "cascading."

The apparent suddenness with which fluting appeared on the late Pleistocene landscape is not an unexpected technological development for a group entering an unfamiliar world, where its individuals undergo rapid changes in order to adapt. As Werner et al. [42] point out with respect to proximal-lateral grinding of hafting elements on Clovis and other early points, understanding the role of fluting contributes to the overall picture of the degree to which colonizing hunter-gatherers, who were dealing with unfamiliar, and perhaps dangerous landscapes, built fail-safe mechanisms into their hunting equipment. Selection works most strongly, and hence is most visible, not during normal times, but in the face of emergencies. In normal times, the distribution of functional traits is bell-shaped, with stabilizing selection continually clipping off the tips of the tail to keep the distribution from moving too far in either direction from the mean. However, in the face of an emergency-for example, moving onto a landscape that is totally different from the one you just left-directional selection can take over and push the distribution in one direction or the other. This translates into the sharply rising cumulative S-curve mentioned above, where you have a limited number of early adopters, followed by a sudden increase in popularity, followed by a leveling off, which signifies saturation. One can see this happening fairly rapidly in the case of Clovis groups, as they moved eastward along the southern edges of the ice sheets, abandoning components of a tool kit that no longer were optimal and creating new technologies based on a pile-up of trait variants that we are only beginning to recognize in the archaeological record [141].

An important point to keep in mind is that despite the fact that I refer to fluting as an adaptation, this does not imply that selection was the only evolutionary process that affected its life history. It is not hard to imagine, for example, that a small population that innovated fluting was the ancestor of a continent-wide migratory pulse across a largely unpopulated continent. Thus, cultural drift could have played an equally significant role in the distribution of fluting.

\section{The Spread of Clovis}

If fluting arose in the Southwest around 13,400 years ago, and if the earliest dates for Clovis in northeastern North American are some 600 years later, can we infer a mechanism or mechanisms for its spread? Researchers have used modeling to track not only the routes of Clovis transmission but the speed at which it occurred [62,108,147-150], but yet to be worked out are the forms of transmission that took place in particular contexts. The difference in age could be a result of an eastward expansion of population [66,151]. An alternative proposal, based on a more restricted radiocarbon-based time span for Clovis-perhaps on the order of 200 years, ca. 13,000-12,800 years ago [16] or 400 years, ca. 13,000-12,600 years ago [64] —is that Clovis spread through rapid transmission of technological knowhow among groups that had resided in North America for some period of time. Distinguishing between the two in the archaeological record is problematic only where there is evidence of a spread of a novel trait into a region that has evidence of a population already in place. In cases where there is no evidence of a pre-existing population, the process must have been demic, as only an immigrant population could have introduced the trait into the region [78]. Given the evidence for pre-Clovis populations in parts of North America, either or both processes could have been responsible.

Stone-reduction sequences are complex procedures that require a significant amount of investment in terms of time and energy to learn effectively [152]. The production of a Clovis point-what I referred to above as a complex technological system-is no exception [26]. Fluting can be a challenging 
technology to master. Fluting occurs after a point is already thinned to approximately $7.5 \mathrm{~mm}$ [47], with failure rates (breakage) among highly skilled knappers in the $10 \%-20 \%$ range [153]. Several studies have shed considerable light on the learning processes involved not only in the transmission of knowledge for manufacturing Clovis points but also in the reinforcement of learning that took place over generations. Central to this reinforcement was the presence of outcrops of highly siliceous stone, such as chert, which were mined for the raw materials that were then shaped into tools. Archaeological evidence from across North America indicates that outcrops were hubs of regional Clovis activity $[26,39,63,68,154]$. For a thinly scattered, mobile population such as Clovis or its immediate descendants, outcrops would have acted as ideal meeting spots because, once found, they would have served as predictable places on an emerging mental landscape map [155-158]. Relative to learning practices, Sholts et al. [39] proposed that outcrops were where Clovis knappers from different groups could observe the tools and techniques used by other knappers, leading to the sharing of technological information. This created a standardization in flaking patterns across the continent, with no evidence of diversification, regional adaptation, or independent innovation [39,149].

Conversely, the shape of Clovis points is highly variable across the continent, with basal concavities in general becoming deeper to the north and northeastern portions of North America. Some studies (e.g., [159]) have indicated that Clovis groups adapted their hunting equipment to the characteristics of prey and local habitat—a case of selection—whereas other studies (e.g., $[67,160])$ have suggested that any variation is attributable to stochastic mechanisms, such as copy error or drift. Figure 7 plots the differences among a sample of 241 Clovis points [159] in terms of relative warps, or principal components, of shape variables, by region. In the study that produced that plot, only Clovis points recovered from unmixed contexts were used. Literally thousands of isolated, surface-collected Clovis points have been found across North America (see later discussion), but they can be problematic because they are necessarily distinctive, meaning that certain morphological features caused them to be picked up in the first place. As a result, they should tend to be less morphologically variable than those found in point assemblages.

Overlap among the regions is evident, but points from the West (red circles) are less variable than those from the East (green circles), particularly along the second relative warp. The wireframes show deformation from the consensus configuration at the ends of each axis to illustrate the Clovis shape space, which is defined along the first relative warp (horizontal axis) by elliptical blades with deeply concave bases at the left, represented by a point from the Mid-Atlantic (Pennsylvania), and by more linear blades with shallow, rounded concave bases to the right, represented by a point from the Northwest (Idaho). Along the second relative warp, shape space is defined by lanceolate blades with straight bases at the upper end, represented by a point from the Southwest (Arizona), and more deltoid blades with deep concave bases at the lower end, represented by a point from the Northeast (Maine). Significance tests showed that in the East, points from the Northeast were significantly different from those from the Mid-Atlantic, Great Lakes, and Midcontinent. This is perhaps not surprising, given that the Northeast apparently was the last region to see colonization by Clovis or slightly later groups, following the retreat of Pleistocene ice from the region around 12,800 years ago or slightly later $[161,162]$. 


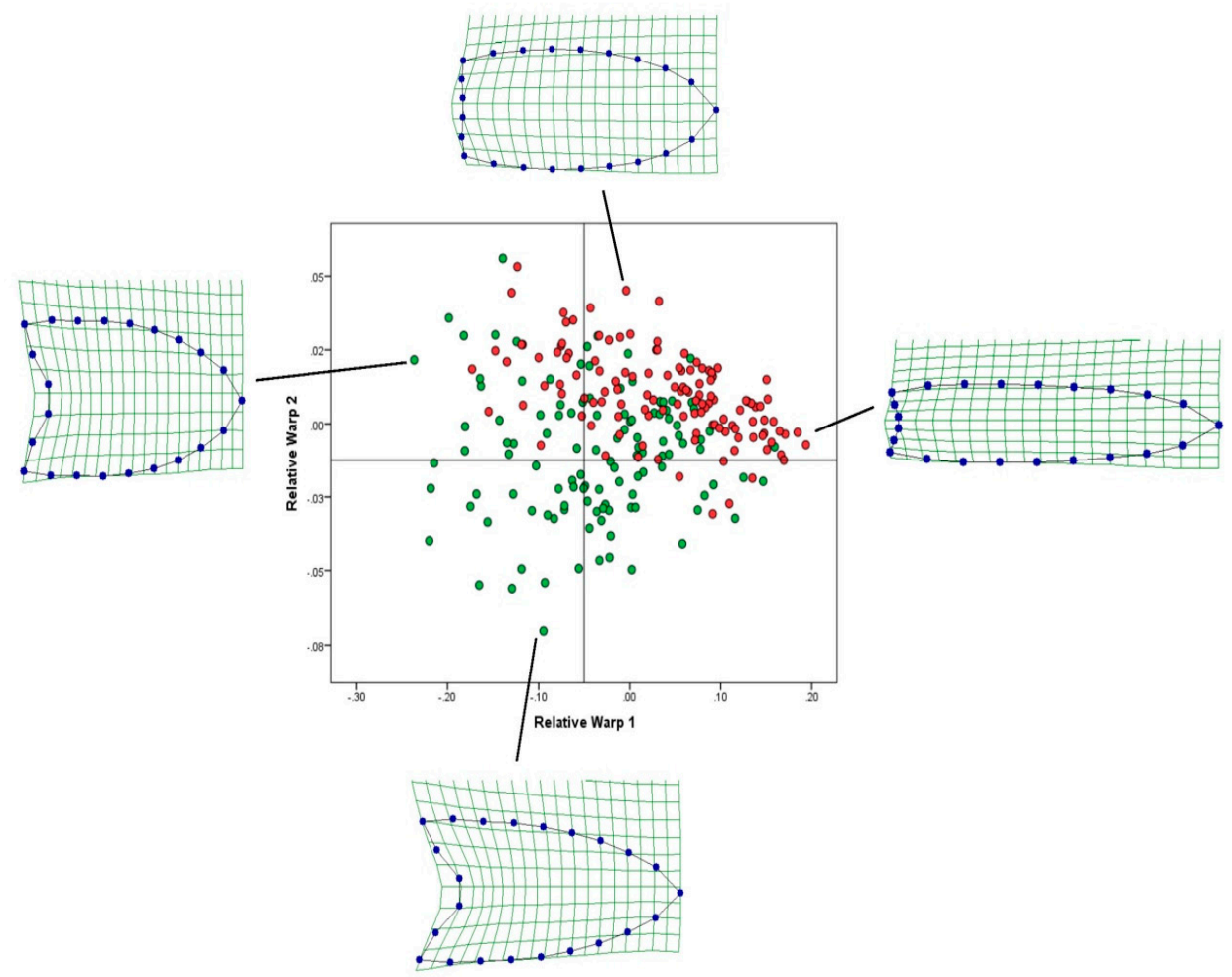

Figure 7. Bivariate plot of two relative warps, or principal components, for 241 Clovis points from various regions of North America. Red circles indicate points from the West, and green circles indicate points from the East. The four images display the shape space defined by the first two relative warps. The upper point is from the Southwest (Arizona), the point at the right is from the Northwest (Idaho), the lower point is from the Northeast (Maine), and the point at the left is from the Mid-Atlantic (Pennsylvania). Reproduced with permission from [159]; figure by Briggs Buchanan.

Based on the results from several studies $[39,149,159]$, it has been suggested that Clovis foragers engaged in two tiers of social learning [163]. The ancestral tier relates to how points were produced, and it reflects more uniformity across space-what can be labeled as conformist transmission [39], which is a kind of learning in which agents copy the most frequent variant(s) they encounter [164]. This learning is sometimes referred to as frequency-dependent copying. With respect to Clovis, groups were still socially connected across large regions of North America and directly transmitting technological knowledge, and perhaps finished items as well, to each other-again, perhaps at outcrops-which resulted in low interregional variation in how points were being flaked. Conversely, the derived tier of social learning relates to point shape, and it exhibits considerably more interregional variation $[149,159]$ (Figure 7), which resulted from individual groups spending more time at different stone-outcrop hubs. Perhaps it should not be surprising that Clovis shape and Clovis flake-removal patterns would be driven by different learning and transmission processes [149,165]. Flaking patterns are a form of "structural integrity," in which key components are more conservative and therefore less likely to change relative to other components.

Within a few hundred years, however, even the ancestral process had collapsed, and there appeared increasing variation in how fluted points were flaked [166]. Perhaps the increase in variation represents a time-transgressive shift, during which Clovis interaction and the direct transmission of knowledge responsible for consistent flaking techniques was on the decline [166]. In other words, once Clovis groups began settling down and, as a result, encountered other groups on a more limited basis, even the conservative aspects of point manufacture - the structural integrity-began to dissolve [149]. The resulting regionalization, especially in eastern North America, produced a multitude of morphologically distinct unfluted and fluted forms (Figure 3), reflecting a "relaxation 
in the pressure to maintain contact with distant kin, a reduction in the spatial scale and openness of social systems, and a steady settling-in and filling of the landscape" [33], (p. 286). If those diverse type forms are proxies for populations, then they should be useful for tracking various groups that budded off and started moving to the Northeast and Southeast, encountering what perhaps were new fitness landscapes, complete with never-before-scaled fitness peaks and requiring a new mix of individualand social-learning strategies.

\section{Conclusions}

As the other papers in this issue make clear, the impacts that human populations have had on North America throughout the terminal Pleistocene and Holocene have been heterogeneous, with the severity of the impacts being highly dependent on time and place. Additionally, these impacts have been influenced by a wide range of factors, including biogeography, immigration and migration, and climate change. Colonizing groups that arrived on the continent 15,300-14,300 years ago found a landscape dissimilar to the one they had previously occupied in Beringia and western Alaska. Beringia at the end of the Pleistocene was a steppe environment, including a mesic environment in southern Beringia [4,167]. A shift to warmer/wetter conditions in Beringia between 14,700 and 13,500 years ago, which was associated with the early Bølling/Allerød interstadial, could have led to groups moving east into western Alaska [168]. Retreating glaciers would have opened up new habitat on the northwest Pacific Coast and the western interior of Canada - the ice-free corridor-both of which could have lured the fast-growing Beringian population into mid-latitude North America and farther south into South America [169,170].

The landscape that colonists found once they moved eastward into unglaciated parts of North America was an immense grassland that fed animals that still inhabit the Great Plains, in addition to extinct fauna, including the Columbian mammoth and giant bison. At some point around 13,400 years ago, a new toolkit appeared - the hallmark of which was the fluted projectile point-and within a few hundred years had spread across the Plains and made its way eastward. How much of the spread was demic diffusion (movement of people) as opposed to cultural diffusion (movement of ideas) is unknown. Regardless of mode, diffusion was rapid, perhaps on the order of 5-8 km per year [66] - a not unreasonable estimate in light of the colonization being driven by high rates of residential mobility [171] that resulted from the large hunting region that a primarily carnivorous diet required. On the Plains and in the Southwest, where Clovis hunters targeted a host of mammalian fauna, including megafauna, diffusion rates might have been faster than in the East. In western regions, initial hunting return rates would have been high, but regeneration rates of megafaunal prey would have been very slow [66], meaning that groups had to continually expand their range. It is not unreasonable to expect that the carriers of Clovis technology would have encountered resident groups as they expanded their range and passed on the technological knowhow of how to produce a fluted point.

By around 12,000 years ago, with perhaps a few exceptions, North America south of the retreating ice sheets had been colonized. By that I mean that the major physiographic regions of the continent had witnessed human groups using them, even if only intermittently. The sheer number of fluted points that have been recovered from across North America, especially in the East (Figure 8), by collectors and amateur and professional archaeologists-literally tens of thousands of points-attests to a rapid filling in of the continent by a fast-moving population. It would be the descendants of this population-alongside descendants of groups that migrated from Asia at later dates-whom Europeans would eventually encounter, beginning with the Norse late in the 10th century AD, followed in the 15th century by the Spanish and then by the French, English, and Dutch. 


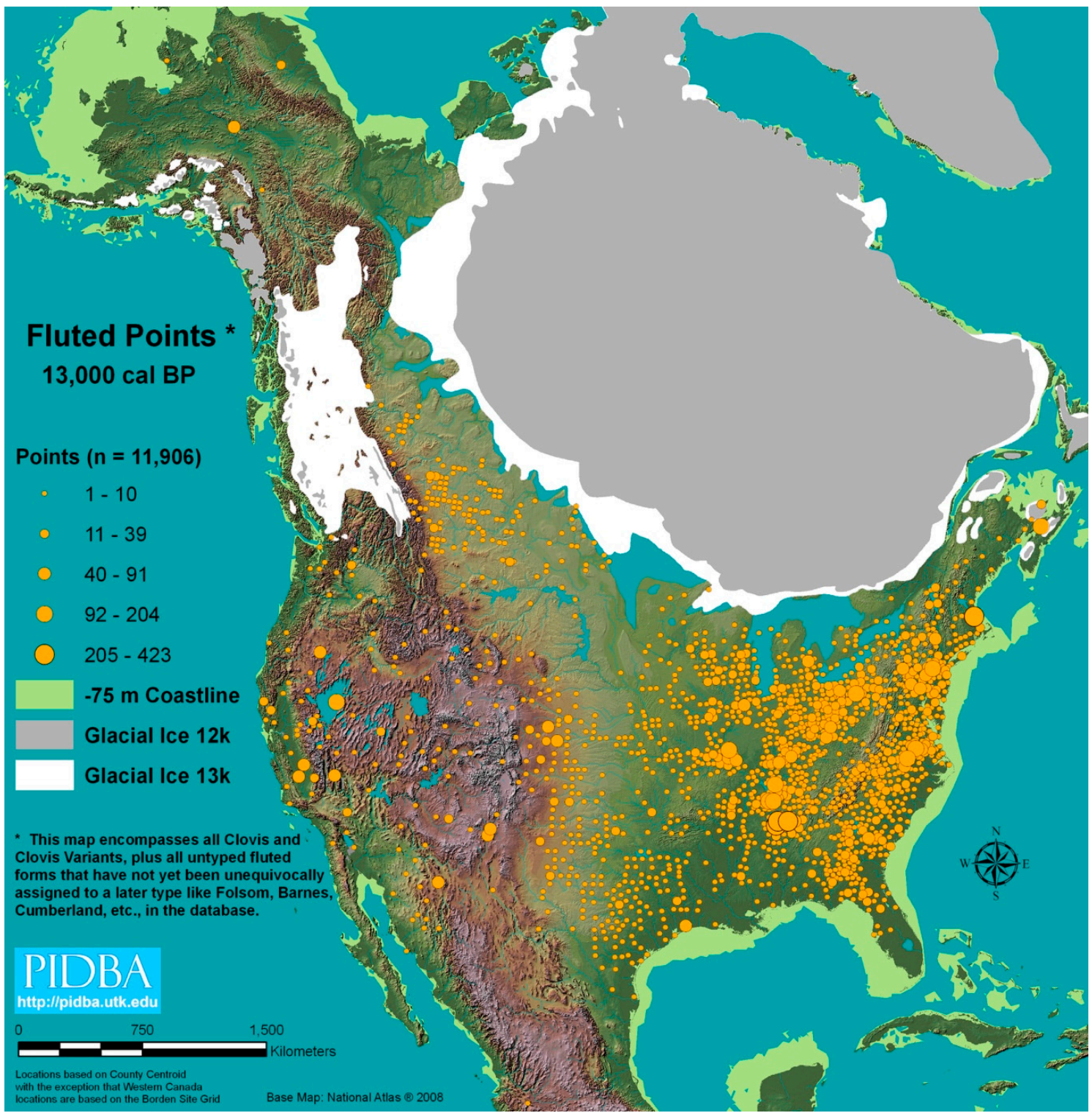

Figure 8. Distribution of almost 12,000 fluted Clovis and Clovis variant projectile points in the Paleoindian Database of the Americas [57].

Funding: This research received no external funding.

Acknowledgments: I thank Jaime Llorca, managing editor of Quaternary, for his kind invitation to submit this paper and Encarni Montoya, Bronwen Whitney, and Valentí Rull for allowing me to participate in this special issue. I thank Briggs Buchanan, Matt Boulanger, Metin Eren, and Mark Collard for helping me over the years to work through some of the points made here. I also thank Mike Waters for permission to use Figure 6 and Mike Collins for permission to use Figures 5 and 7. Finally, I thank three anonymous reviewers for their suggestions for improving the manuscript and Sara Martínez, assistant editor of Quaternary, for her technical help.

Conflicts of Interest: The author declares no conflict of interest.

\section{References}

1. Stanford, D.; Bradley, B. Across Atlantic Ice: The Origin of America's Clovis Culture; University of California Press: Berkeley, CA, USA, 2012.

2. Blong, J.C. Late-glacial hunter-gatherers in the Central Alaska Range and the role of upland ecosystems in the peopling of Alaska. PaleoAmerica 2018, 4, 103-133. [CrossRef] 
3. Goebel, T.; Waters, M.R.; O'Rourke, D.H. The Late Pleistocene dispersal of modern humans in the Americas. Science 2008, 319, 1497-1502. [CrossRef] [PubMed]

4. Hoffecker, J.F.; Elias, S.A.; O'Rourke, D.H.; Scott, G.R.; Bigelow, N.H. Beringia and the global dispersal of modern humans. Evol. Anthropol. 2016, 25, 64-78. [CrossRef] [PubMed]

5. Kemp, B.M.; Schurr, T.G. Ancient and modern genetic variation in the Americas. In Human Variation in the Americas; Auerbach, B.M., Ed.; Southern Illinois University Press: Carbondale, IL, USA, 2010; pp. 12-50.

6. Llamas, B.; Fehren-Schmitz, L.; Valverde, G.; Soubrier, J.; Mallick, S.; Rohland, N.; Nordenfelt, S.; Valdiosera, C.; Richards, S.M.; Rohrlach, A.; et al. Ancient mitochondrial DNA provides high resolution time scale of the peopling of the Americas. Sci. Adv. 2016, 2, e1501385. [CrossRef] [PubMed]

7. Moreno-Mayar, J.V.; Vinner, L.; de Barros Damgaard, P.; de la Fuente, C.; Chan, J.; Spence, J.P.; Allentoft, M.E.; Vimala, T.; Racimo, F.; Pinotti, T.; et al. Early human dispersals within the Americas. Science 2018, 362. [CrossRef] [PubMed]

8. Morrow, J.E. Review of "Across Atlantic Ice: The Origin of America's Clovis Culture", by Stanford, D.J., Bradley, B.A. Lithic Technol. 2014, 39, 76-78. [CrossRef]

9. O'Rourke, D.H.; Raff, J.A. The human genetic history of the Americas: The final frontier. Curr. Biol. 2010, 20, R202-R207. [CrossRef]

10. Posth, C.; Nakatsuka, N.; Lazaridis, I.; Skoglund, P.; Mallick, S.; Lamnidis, T.C.; Rohland, N.; Nägele, K.; Adamski, N.; Bertolini, E.; et al. Reconstructing the deep population history of Central and South America. Cell 2018, 175, 1185-1197. [CrossRef]

11. Raff, J.; Bolnick, D.A. Does mitochondrial haplogroup $X$ indicate ancient trans-Atlantic migration to the Americas? A critical reevaluation. PaleoAmerica 2015, 4, 297-304. [CrossRef]

12. Raff, J.A.; Bolnick, D.A.; Tackney, J.; O’Rourke, D.H. Ancient DNA perspectives on American colonization and population history. Am. J. Phys. Anthropol. 2010, 146, 503-514. [CrossRef]

13. Raghavan, M.; Skoglund, P.; Graf, K.E.; Metspalu, M.; Albrechtsen, A.; Moltke, I.; Rasmussen, S.; Stafford, T.W., Jr.; Orlando, L.; Metspalu, E.; et al. Upper Palaeolithic Siberian genome reveals dual ancestry of Native Americans. Nature 2013, 505, 87-91. [CrossRef] [PubMed]

14. Raghavan, M.; Steinrücken, M.; Harris, K.; Schiffels, S.; Rasmussen, S.; DeGiorgio, M.; Albrechtsen, A.; Valdiosera, C.; Ávila-Arcos, M.C.; Malaspinas, A.-S.; et al. Genomic evidence for the Pleistocene and Recent population history of Native Americans. Science 2015, 349, 841. [CrossRef] [PubMed]

15. Rasmussen, M.; Anzick, S.L.; Waters, M.R.; Skoglund, P.; DeGiorgio, M.; Stafford, T.W., Jr.; Rasmussen, S.; Moltke, I.; Albrechtsen, A.; Doyle, S.M.; et al. The genome of a late Pleistocene human from a Clovis burial site in western Montana. Nature 2014, 506, 225-229. [CrossRef] [PubMed]

16. Waters, M.R.; Stafford, T.W., Jr. Redefining the age of Clovis: Implications for the peopling of the Americas. Science 2007, 315, 1122-1126. [CrossRef] [PubMed]

17. Braje, T.J.; Dillehay, T.D.; Erlandson, J.M.; Klein, R.G.; Rick, T.C. Finding the first Americans. Science 2017, 358, 592-594. [CrossRef]

18. Erlandson, J.M.; Graham, M.H.; Bourque, B.J.; Corbett, D.; Estes, J.A.; Steneck, R.S. The kelp highway hypothesis: Marine ecology, the coastal migration theory, and the peopling of the Americas. J. Island Coast. Archaeol. 2007, 2, 161-174. [CrossRef]

19. Fladmark, K.R. Routes: Alternate migration corridors for early man in North America. Am. Antiq. 1979, 44, 55-69. [CrossRef]

20. Gilbert, M.T.P.; Jenkins, D.L.; Götherstrom, A.; Naveran, N.; Sanchez, J.J.; Hofreiter, M.; Thomsen, P.F.; Binladen, J.; Higham, T.F.G.; Yohe, R.M.; et al. DNA from pre-Clovis human coprolites in Oregon, North America. Science 2008, 320, 786-789. [CrossRef]

21. Freeman, A. Why the ice-free corridor is still relevant to the peopling of the New World. In Stones, Bones, and Profiles; Kornfeld, M., Huckell, B.B., Eds.; University Press of Colorado: Boulder, CO, USA, 2016; pp. 51-74.

22. Ives, J.W.; Froese, D.; Supernant, K.; Yanicki, J. Vectors, vestiges, and valhallas: Rethinking the corridor. In Paleoamerican Odyssey; Graf, K.E., Ketron, C.V., Waters, M.R., Eds.; Center for the Study of the First Americans, Texas A\&M University: College Station, TX, USA, 2014; pp. 149-169.

23. Pederson, M.W.; Ruter, A.; Schweger, C.; Friebe, H.; Staff, R.A.; Kjeldsen, K.K.; Mendoza, M.L.Z.; Beaudoin, A.B.; Zutter, C.; Larsen, N.K.; et al. Postglacial viability and colonization in North America's Ice-Free Corridor. Nature 2016, 537, 45-49. [CrossRef] 
24. Potter, B.A.; Baichtal, J.F.; Beaudoin, A.B.; Fehren-Schmitz, L.; Haynes, C.V.; Holliday, V.T.; Holmes, C.E.; Ives, J.W.; Kelly, R.; Llamas, B.; et al. Current evidence allows multiple models for the peopling of the Americas. Sci. Adv. 2018, 4, eaat5473. [CrossRef]

25. Potter, B.A.; Reuther, J.D.; Holliday, V.T.; Holmes, C.E.; Miller, D.S.; Schmuck, N. Early colonization of Beringia and northern North America: Chronology, routes, and adaptive strategies. Quat. Int. 2017, 444, 36-55. [CrossRef]

26. Bradley, B.A.; Collins, M.B.; Hemmings, A. Clovis Technology; Archaeological Series 17; International Monographs in Prehistory: Ann Arbor, MI, USA, 2010.

27. Buchanan, B.; Chao, A.; Chiu, C.H.; Colwell, R.K.; O’Brien, M.J.; Werner, A.; Eren, M.I. Environment-induced changes in selective constraints on social learning during the peopling of the Americas. Sci. Rep. 2017, 7, 44431. [CrossRef] [PubMed]

28. Gingerich, J.A.M. (Ed.) In the Eastern Fluted Point Tradition; University of Utah Press: Salt Lake City, UT, USA, 2013.

29. Gingerich, J.A.M. (Ed.) In the Eastern Fluted Point Tradition; University of Utah Press: Salt Lake City, UT, USA, 2018; Volume 2.

30. Graf, K.E.; Ketron, C.V.; Waters, M.R. (Eds.) Paleoamerican Odyssey; Center for the Study of the First Americans, Texas A\&M University: College Station, TX, USA, 2014.

31. Haynes, G. The Early Settlement of North America: The Clovis Era; Cambridge University Press: Cambridge, UK, 2002.

32. Meltzer, D.J. Peopling of North America. In The Quaternary Period in the United States; Gillespie, A., Porter, S.C., Atwater, B., Eds.; Elsevier: New York, NY, USA, 2004; pp. 539-563.

33. Meltzer, D.J. First Peoples in a New World: Colonizing Ice Age America; University of California Press: Berkeley, CA, USA, 2009.

34. Meltzer, D.J. Pleistocene overkill and North American mammalian extinctions. Ann. Rev. Anthropol. 2015, 44, 33-53. [CrossRef]

35. Smallwood, A.M.; Jennings, T. (Eds.) Clovis: On the Edge of a New Understanding; Texas A\&M University Press: College Station, TX, USA, 2015.

36. O’Brien, M.J.; Lyman, R.L.; Buchanan, B.; Collard, M. A review of late Pleistocene North American bone and ivory tools. In Osseous Projectile Weaponry; Langley, M.C., Ed.; Springer: Dordrecht, The Netherlands, 2016; pp. 221-235.

37. Bradley, B.A. Paleo-Indian flaked stone technology in the North American High Plains. In From Kostenki to Clovis: Upper Paleolithic-Paleo-Indian Adaptations; Sofer, O., Praslov, N.D., Eds.; Plenum: New York, NY, USA, 1993; pp. 251-262.

38. Morrow, J.E. Fluted point manufacture: A perspective from the Ready Lincoln Hills site, 11JY46, Jersey County, Illinois. Midcont. J. Archaeol. 1995, 20, 167-191.

39. Sholts, S.B.; Stanford, D.J.; Flores, L.M.; Wärmländer, S.K.T.S. Flake scar patterns of Clovis points analyzed with a new digital morphometrics approach: Evidence for direct transmission of technological knowledge across early North America. J. Archaeol. Sci. 2012, 39, 3018-3026. [CrossRef]

40. Wormington, H.M. Ancient Man in North America; Denver Museum of Natural History Popular Series, no. 4; Denver Museum of Natural History: Denver, CO, USA, 1957.

41. Eren, M.I.; Buchanan, B. Clovis technology. In eLS; John Wiley \& Sons Ltd: Chichester, UK, 2016; pp. 1-9. [CrossRef]

42. Werner, A.; Kramer, A.; Reedy, C.; Bebber, M.R.; Pargeter, J.; Eren, M.I. Experimental assessment of proximal-lateral edge grinding on haft damage using replicated Late Pleistocene (Clovis) stone projectile points. Archaeol. Anthropol. Sci. 2018. [CrossRef]

43. Cook, H.J. Glacial age man in New Mexico. Sci. Am. 1928, 139, 38-40. [CrossRef]

44. Renaud, E.B. Prehistoric flaked points from Colorado and neighboring districts. Proc. Colo. Mus. Nat. Hist. 1931, 10, 6-17.

45. Roberts, F.H.H. A Folsom Complex; Preliminary Report on Investigations at the Lindenmeier Site in Northern Colorado; Smithsonian Miscellaneous Collections 94; Smithsonian Institution: Washington, DC, USA, 1935.

46. Story, B.A.; Eren, M.I.; Thomas, K.; Buchanan, B.; Meltzer, D.J. Why are Clovis fluted points more resilient than non-fluted lanceolate points? A quantitative assessment of breakage patterns between experimental models. Archaeometry 2018. [CrossRef] 
47. Thomas, K.A.; Story, B.A.; Eren, M.I.; Buchanan, B.; Andrews, B.N.; O’Brien, M.J.; Meltzer, D.J. Explaining the origin of fluting in North American Pleistocene weaponry. J. Archaeol. Sci. 2017, 81, 23-30. [CrossRef]

48. Hutchings, W.K. Finding the Paleoindian spearthrower: Quantitative evidence for mechanically-assisted propulsion of lithic armatures during the North American Paleoindian period. J. Archaeol. Sci. 2015, 55, 34-41. [CrossRef]

49. Lyman, R.L.; O'Brien, M.J.; Hayes, V. A mechanical and functional study of bone rods from the Richey-Roberts Clovis cache, Washington, U.S.A. J. Archaeol. Sci. 1998, 25, 887-906. [CrossRef]

50. Cotter, J.L. The occurrence of flints and extinct animals in pluvial deposits near Clovis, New Mexico: Part IV, report on excavation at the gravel pit, 1936. Proc. Acad. Nat. Sci. Phila. 1937, 89, 1-16.

51. Cotter, J.L. The occurrence of flints and extinct animals in pluvial deposits near Clovis, New Mexico: Part VI, report on field season of 1937. Proc. Acad. Nat. Sci. Phila. 1938, 90, 113-117.

52. Figgins, J.D. The antiquity of man in America. Nat. Hist. 1927, 27, 229-239.

53. Hinsley, C.M., Jr. Savages and Scientists: The Smithsonian Institution and the Development of American Archaeology, 1846-1910; Smithsonian Institution Press: Washington, DC, USA, 1981.

54. Meltzer, D.J. The Great Paleolithic War: How Science Forged an Understanding of America's Ice Age Past; University of Chicago Press: Chicago, IL, USA, 2015.

55. Anderson, D.G.; Faught, M.K. The distribution of fluted Paleoindian projectile points: Update 1998. Archaeol. East. N. Am. 1998, 26, 163-187.

56. Anderson, D.G.; Faught, M.K. Palaeoindian artefact distributions: Evidence and implications. Antiquity 2000, 74, 507-513. [CrossRef]

57. Anderson, D.G.; Miller, D.S.; Yerka, S.J.; Gillam, J.C.; Johanson, D.T.; Goodyear, A.C.; Smallwood, A.M. Paleoindian database of the Americas 2010: Current status and findings. Archaeol. East. N. Am. 2010, 38, 63-90.

58. Haynes, C.V., Jr. Fluted projectile points: Their age and dispersion. Science 1964, 145, 1408-1413. [CrossRef]

59. Holliday, V.T. The evolution of Paleoindian geochronology and typology on the Great Plains. Geoarchaeology 2000, 15, 227-290. [CrossRef]

60. Prasciunas, M.M. Mapping Clovis: Projectile points, behavior, and bias. Am. Antiq. 2011, 76, $107-126$. [CrossRef]

61. Sanchez, G.; Holliday, V.T.; Gaines, E.P.; Arroyo-Cabrales, J.; Martínez-Tagüeña, N.; Kowler, A.; Lange, T.; Hodgins, G.W.L.; Mentzer, S.M.; Sanchez-Morales, I. Human (Clovis)-gomphothere (Cuvieronius sp.) association 13,390 calibrated yBP in Sonora, Mexico. Proc. Natl. Acad. Sci. USA 2014, 111, 10972-10977. [CrossRef] [PubMed]

62. Smallwood, A.M. Clovis technology and settlement in the American Southeast: Using biface analysis to evaluate dispersal models. Am. Antiq. 2012, 77, 689-713. [CrossRef]

63. Smith, H.L.; Goebel, T. Origins and spread of fluted-point technology in the Canadian Ice-Free Corridor and eastern Beringia. Proc. Natl. Acad. Sci. USA 2018, 115, 4116-4121. [CrossRef]

64. Waters, M.R.; Stafford, T.W., Jr. The first Americans: A review of the evidence for the late-Pleistocene peopling of the Americas. In Paleoamerican Odyssey; Graf, K.E., Ketron, C.V., Waters, M.R., Eds.; Center for the Study of the First Americans, Texas A\&M University: College Station, TX, USA, 2014; pp. 541-560.

65. Beck, C.; Jones, G.T. Clovis and Western Stemmed: Population migration and the meeting of two technologies in the Intermountain West. Am. Antiq. 2010, 75, 81-116. [CrossRef]

66. Hamilton, M.J.; Buchanan, B. Spatial gradients in Clovis-age radiocarbon dates across North America suggest rapid colonization from the north. Proc. Natl. Acad. Sci. USA 2007, 104, 15625-15630. [CrossRef]

67. Morrow, J.E.; Morrow, T.A. Geographic variation in fluted projectile points: A hemispheric perspective. Am. Antiq. 1999, 64, 215-231. [CrossRef]

68. Waters, M.R.; Forman, S.L.; Jennings, T.A.; Nordt, L.C.; Driese, S.G.; Feinberg, J.M.; Keene, J.L.; Halligan, J.; Lindquist, A.; Pierson, J.; et al. The Buttermilk Creek Complex and the origins of Clovis at the Debra L. Friedkin site, Texas. Science 2011, 331, 1599-1603. [CrossRef]

69. Bradley, J.W.; Spiess, A.; Boisvert, R.A.; Boudreau, J. What's the point? Modal forms and attributes of Paleoindian bifaces in the New England-Maritimes Region. Archaeol. East. N. Am. 2008, 36, 119-172.

70. Curran, M.L. Palaeoindians in the Northeast: The problem of dating fluted point sites. Rev. Archaeol. 1996, $17,2-11$. 
71. Haynes, C.V., Jr.; Donahue, D.J.; Jull, A.J.T.; Zabel, T.H. Application of accelerator dating to fluted point Paleoindian sites. Archaeol. East. N. Am. 1984, 12, 184-191.

72. Levine, M.A. Accommodating age: Radiocarbon results and fluted point sites in northeastern North America. Archaeol. East. N. Am. 1990, 18, 33-63.

73. Miller, D.S.; Gingerich, J.A.M. Regional variation in the terminal Pleistocene and early Holocene radiocarbon record of eastern North America. Quat. Res. 2013, 79, 175-188. [CrossRef]

74. Miller, D.S.; Gingerich, J.A.M. Paleoindian chronology and the eastern fluted point tradition. In In the Eastern Fluted Point Tradition; Gingerich, J.A.M., Ed.; University of Utah Press: Salt Lake City, UT, USA, 2013; pp. 9-37.

75. Robinson, B.S.; Ort, J.C.; Eldridge, W.A.; Burke, A.L.; Pelletier, B.G. Paleoindian aggregation and social context at Bull Brook. Am. Antiq. 2009, 74, 423-447. [CrossRef]

76. Ahler, S.A.; Geib, P.R. Why flute? Folsom point design and adaptation. J. Archaeol. Sci. 2000, 27, 799-820. [CrossRef]

77. Crabtree, D.E. A stoneworker's approach to analyzing and replicating the Lindenmeier Folsom. Tebiwa 1966, 9, 3-39.

78. Collard, M.; Buchanan, B.; Hamilton, M.J.; O’Brien, M.J. Spatiotemporal dynamics of the Clovis-Folsom transition. J. Archaeol. Sci. 2010, 37, 2513-2519. [CrossRef]

79. Jodry, M.A.; Turner, M.D.; Spero, V.; Turner, J.C.; Stanford, D. Folsom in the Colorado high country: The Black Mountain site. Curr. Res. Pleistocene 1996, 13, 25-27.

80. Meltzer, D.J. Folsom: New Archaeological Investigations of a Classic Bison Kill; University of California Press: Berkeley, CA, USA, 2006.

81. Root, M.J.; William, J.D.; Kay, M.; Shifrin, L.K. Folsom ultrathin biface and radial break tools in the Knife River Flint quarry area. In Folsom Lithic Technology, Explorations in Structure and Variation; Amick, D.S., Ed.; Archaeological Series 12; International Monographs in Prehistory: Ann Arbor, MI, USA, 1999; pp. 144-168.

82. Taylor, R.E.; Haynes, C.V.; Stuiver, M. Clovis and Folsom age estimates: Stratigraphic context and radiocarbon calibration. Antiquity 1996, 70, 515-525. [CrossRef]

83. Cannon, M.D.; Meltzer, D.J. Early Paleoindian foraging: Examining the faunal evidence for large mammal specialization and regional variability in prey choice. Quat. Sci. Rev. 2004, 23, 1955-1987. [CrossRef]

84. DeAngelis, J.A.; Lyman, R.L. Evaluation of the Early Paleo-Indian zooarchaeological record as evidence of diet breadth. Archaeol. Anthropol. Sci. 2018, 10, 555-570. [CrossRef]

85. Haynes, G.; Hutson, J.M. Clovis-era subsistence: Regional variability, continental patterning. In Paleoamerican Odyssey; Graf, K.E., Ketron, C.V., Waters, M.R., Eds.; Center for the Study of the First Americans, Texas A\&M University: College Station, TX, USA, 2014; pp. 293-309.

86. Surovell, T.A.; Waguespack, N.M. Human prey choice in the Late Pleistocene and its relation to megafaunal extinction. In American Megafaunal Extinctions at the End of the Pleistocene; Haynes, G., Ed.; Springer: New York, NY, USA, 2009; pp. 77-105.

87. Waguespack, N.M.; Surovell, T.A. Clovis hunting strategies, or how to make out on plentiful resources. Am. Antiq. 2003, 68, 333-352. [CrossRef]

88. Amick, D.S. Folsom Diet Breadth and Land Use in the American Southwest. Ph.D. Dissertation, Department of Anthropology, University of New Mexico, Albuquerque, NM, USA, 1994.

89. MacDonald, D.H. Subsistence, sex, and cultural transmission in Folsom culture. J. Anthropol. Archaeol. 1998, 17, 217-239. [CrossRef]

90. Hester, J.J. Blackwater Draw Locality No. 1: A Stratified Early Man Site in Eastern New Mexico; Fort Burgwin Research Center Publication no. 8; Fort Burgwin Research Center: Ranchos de Taos, NM, USA, 1972.

91. Bement, L.C. Bison Hunting at Cooper Site: Where Lightning Bolts Drew Thundering Herds; University of Oklahoma Press: Norman, OK, USA, 1999.

92. Bement, L.C. View from a kill: The Cooper site Folsom lithic assemblage. In Folsom Lithic Technology. Explorations in Structure and Variation; Amick, D.S., Ed.; Archaeological Series 12; International Monographs in Prehistory: Ann Arbor, MI, USA, 1999; pp. 111-121.

93. Hofman, J.L.; Todd, L.C.; Schultz, C.B.; Hendy, W. The Lipscomb bison quarry: Continuing investigation at a Folsom kill-butchery site on the Southern Plains. Bull. Tex. Archeol. Soc. 1989, 60, 149-189.

94. Johnson, E. (Ed.) Lubbock Lake. Late Quaternary Studies on the Southern High Plains; Texas A\&M University Press: College Station, TX, USA, 1987. 
95. Harrison, B.R.; Smith, H.C. A test excavation of the Lake Theo site, Briscoe County, Texas. Panhand. Plains Hist. Rev. 1975, 48, 70-106.

96. Grayson, D.K.; Meltzer, D.J. Requiem for North American overkill. J. Archaeol. Sci. 2003, 30, 585-593. [CrossRef]

97. Grayson, D.K.; Meltzer, D.J. Clovis hunting and large mammal extinction: A critical review of the evidence. J. World Prehist. 2002, 16, 313-359. [CrossRef]

98. Collins, M.B. Clovis and Folsom lithic technology on and near the Southern Plains: Similar ends, different means. In Folsom Lithic Technology, Explorations in Structure and Variation; Amick, D.S., Ed.; Archaeological Series 12; International Monographs in Prehistory: Ann Arbor, MI, USA, 1999; pp. 12-38.

99. Frison, G.C.; Bradley, B.A. Folsom Tools and Technology at the Hanson Site, Wyoming; University of New Mexico Press: Albuquerque, NM, USA, 1980.

100. Root, M.J.; MacDonald, D.; Emerson, A.M. The Bobtail Wolf site: An update on recent excavations. Curr. Res. Pleistocene 1996, 13, 38-40.

101. Howard, C.D. The Clovis point: Characteristics and type description. Plains Anthropol. 1990, 35, $255-262$. [CrossRef]

102. O’Brien, M.J.; Boulanger, M.T.; Buchanan, B.; Collard, M.; Lyman, R.L.; Darwent, J. Innovation and cultural transmission in the American Paleolithic: Phylogenetic analysis of eastern Paleoindian projectile-point classes. J. Anthropol. Archaeol. 2014, 34, 100-119. [CrossRef]

103. Roosa, W.B. Some Great Lakes fluted point types. Mich. Archaeol. 1965, 9, 89-102.

104. Smith, H.L.; Smallwood, A.M.; DeWitt, T.J. Defining the normative range of Clovis fluted point shape using geographic models of geometric morphometric variation. In Clovis: On the Edge of a New Understanding; Smallwood, A.M., Jennings, T.A., Eds.; Texas A\&M University Press: College Station, TX, USA, 2015; pp. 161-180.

105. Lothrop, J.C.; Lowery, D.L.; Spiess, A.E.; Ellis, C.J. Early human settlement of northeastern North America. PaleoAmerica 2016, 2, 192-251. [CrossRef]

106. Miller, D.S.; Holliday, V.T.; Bright, J. Clovis across the continent. In Paleoamerican Odyssey; Graf, K.E., Ketron, C.V., Waters, M.R., Eds.; Center for the Study of the First Americans, Texas A\&M University: College Station, TX, USA, 2014; pp. 207-220.

107. Mason, R.J. The Paleo-Indian tradition in eastern North America. Curr. Anthropol. 1962, 3, 227-278. [CrossRef]

108. Anderson, D.G. The Paleoindian colonization of eastern North America: A view from the southeastern United States. In Early Paleoindian Economies of Eastern North America; Tankersely, K.B., Isaac, B.L., Eds.; JAI Press: Greenwich, CT, USA, 1990; pp. 163-216.

109. Anderson, D.G.; O'Steen, L.D.; Sassaman, K.E. Chronological considerations. In The Paleoindian and Early Archaic Southeast; Anderson, D.G., Sassaman, K.E., Eds.; University of Alabama Press: Tuscaloosa, AL, USA, 1996; pp. 3-15.

110. Bradley, B.A. Sloan site biface and projectile point technology. In Sloan: A Paleoindian Dalton Cemetery in Arkansas; Morse, D.F., Ed.; Smithsonian Institution Press: Washington, DC, USA, 1997; pp. 53-57.

111. Brennan, L.A. A compilation of fluted points of eastern North America by count and distribution: An AENA project. Archaeol. East. N. Am. 1982, 10, 27-46.

112. Bullen, R.P. A Guide to the Identification of Florida Projectile Points; Florida State Museum: Gainesville, FL, USA, 1968.

113. Goodyear, A.C. The chronological position of the Dalton horizon in the southeastern United States. Am. Antiq. 1982, 47, 382-395. [CrossRef]

114. Lewis, T.M.N. The Cumberland point. Okla. Anthropol. Soc. Bull. 1954, 2, 7-8.

115. MacDonald, G.F. Debert: A Palaeo-Indian Site in Central Nova Scotia; Anthropology Paper no. 16; National Museums of Canada: Ottawa, ON, Canada, 1968.

116. Fogelman, G.L.; Lantz, S.W. The Pennsylvania Fluted Point Survey; Fogelman: Turbotville, PA, USA, 2006.

117. Hranicky, W.J. Middle Atlantic Projectile Point Typology and Nomenclature; Special Publication, no. 33; Archaeological Society of Virginia: Courtland, VA, USA, 1994.

118. Thulman, D.K. A typology of fluted points from Florida. Fla. Anthropol. 2007, 60, 63-75.

119. Thulman, D.K. Discriminating Paleoindian point types from Florida using landmark geometric morphometrics. J. Archaeol. Sci. 2012, 39, 1599-1607. [CrossRef] 
120. Webb, S.D. (Ed.) First Floridians and Last Mastodons: The Page-Ladson Site in the Aucilla River; Springer: Dordrecht, The Netherlands, 2006.

121. Halligan, J.J.; Waters, M.R.; Perrotti, A.; Owens, I.J.; Feinberg, J.M.; Bourne, M.D.; Fenerty, B.; Winsborough, B.; Carlson, D.; Fisher, D.C.; et al. Pre-Clovis occupation 14,550 years ago at the Page-Ladson site, Florida, and the peopling of the Americas. Sci. Adv. 2016, 2, e1600375. [CrossRef]

122. Eren, M.I.; Patten, R.J.; O'Brien, M.J.; Meltzer, D.J. Refuting the technological cornerstone of the Ice-Age Atlantic crossing hypothesis. J. Archaeol. Sci. 2013, 40, 2934-2941. [CrossRef]

123. Morrow, J.E.; Fiedel, S.J.; Johnson, D.L.; Kornfeld, M.; Rutledge, M.; Wood, W.R. Pre-Clovis in Texas? A critical assessment of the "Buttermilk Creek Complex". J. Archaeol. Sci. 2012, 39, 3677-3682. [CrossRef]

124. Driese, S.G.; Nordt, L.C.; Waters, M.R.; Keene, J.L. Analysis of site formation history and potential disturbance of stratigraphic context in vertisols at the Debra L. Friedkin archaeological site in central Texas, USA. Geoarchaeology 2013, 28, 221-248. [CrossRef]

125. Jennings, T.A. Clovis, Folsom, and Midland components at the Debra L. Friedkin site, Texas: Context, chronology, and assemblages. J. Archaeol. Sci. 2012, 39, 3239-3247. [CrossRef]

126. Williams, T.J.; Collins, M.B.; Rodrigues, K.; Rink, W.J.; Velchoff, N.; Keen-Zebert, A.; Gilmer, A.; Frederick, C.D.; Ayala, S.J.; Prewitt, E.R. Evidence of an early projectile point technology in North America at the Gault site, Texas, USA. Sci. Adv. 2018, 4, eaar5954. [CrossRef] [PubMed]

127. Haynes, G. The millennium before Clovis. Paleoamerica 2015, 1, 134-162. [CrossRef]

128. Buchanan, B.; Collard, M. Phenetics, cladistics, and the search for the Alaskan ancestors of the Paleoindians: A reassessment of relationships among the Clovis, Nenana, and Denali archaeological complexes. J. Archaeol. Sci. 2008, 35, 1683-1694. [CrossRef]

129. Goebel, T. The search for a Clovis progenitor in subarctic Siberia. In Entering America: Northeast Asia and Beringia before the Last Glacial Maximum; Madsen, D.B., Ed.; University of Utah Press: Salt Lake City, UT, USA, 2004; pp. 311-356.

130. Goebel, T. What is the Nenana Complex? Raw material procurement and technological organization at Walker Road, central Alaska. In From the Yenisei to the Yukon: Interpreting Lithic Assemblage Variability in Late Pleistocene/Early Holocene Beringia; Goebel, T., Buvit, I., Eds.; Center for the Study of the First Americans, Texas A\&M University: College Station, TX, USA, 2011; pp. 99-114.

131. Goebel, T.; Powers, R.; Bigelow, N. The Nenana Complex of Alaska and Clovis origins. In Clovis Origins and Adaptations; Bonnichsen, R., Turnmire, K.L., Eds.; Center for the Study of the First Americans, Oregon State University: Corvallis, OR, USA, 1991; pp. 49-79.

132. Smith, H.L.; Rasic, J.T.; Goebel, T. Biface traditions of northern Alaska and their role in the peopling of the Americas. In Paleoamerican Odyssey; Graf, K.E., Ketron, C.V., Waters, M.R., Eds.; Center for the Study of the First Americans, Texas A\&M University: College Station, TX, USA, 2014; pp. 105-123.

133. Straus, L.G.; Meltzer, D.J.; Goebel, T. Ice age Atlantis? Exploring the Solutrean-Clovis "connection". World Archaeol. 2005, 37, 507-532. [CrossRef]

134. Hoffecker, J.F.; Elias, S.A. Human Ecology of Beringia; Columbia University Press: New York, NY, USA, 2007.

135. Prasciunas, M.M.; Surovell, T.A. Reevaluating the duration of Clovis: The problem of nonrepresentative radiocarbon. In Clovis: On the Edge of a New Understanding; Smallwood, A.M., Jennings, T.A., Eds.; Texas A\&M University Press: College Station, TX, USA, 2015; pp. 21-35.

136. Waguespack, N.M. Why we're still arguing about the Pleistocene occupation of the Americas. Evol. Anthropol. 2007, 16, 63-74. [CrossRef]

137. Jennings, T.A.; Waters, M.R. Pre-Clovis lithic technology at the Debra L. Friedkin site, Texas: Comparisons to Clovis through site-level behavior, technological trait-list, and cladistics analyses. Am. Antiq. 2014, 79, $25-44$. [CrossRef]

138. O’Brien, M.J.; Lyman, R.L. Applying Evolutionary Archaeology: A Scientific Approach; Kluwer Academic/Plenum: New York, NY, USA, 2000.

139. O’Brien, M.J.; Buchanan, B.; Eren, M.I. (Eds.) Convergent Evolution in Stone-Tool Technology; MIT Press: Cambridge, MA, USA, 2018.

140. O’Brien, M.J.; Boulanger, M.T.; Collard, M.; Buchanan, B.; Tarle, L.; Straus, L.G.; Eren, M.I. On thin ice: Problems with Stanford and Bradley's Solutrean-Clovis hypothesis. Antiquity 2014, 88, 606-624. [CrossRef]

141. O'Brien, M.J. More on Clovis learning: Individual-level processes aggregate to form population-level patterns. PaleoAmerica 2019, in press. 
142. Schiffer, M.B. Some relationships between behavioral and evolutionary archaeologies. Am. Antiq. 1996, 61, 643-662. [CrossRef]

143. Schiffer, M.B. The devil is in the details: The cascade model of invention processes. Am. Antiq. 2005, 70, 485-502. [CrossRef]

144. Mesoudi, A.; O’Brien, M.J. The learning and transmission of hierarchical cultural recipes. Biol. Theory 2008, 3, 63-72. [CrossRef]

145. Gould, S.J.; Vrba, E.S. Exaptation-A missing term in the science of form. Paleobiology 1982, 1, 4-15. [CrossRef]

146. Mayr, E. The Growth of Biological Thought: Diversity, Evolution, and Inheritance; Belknap Press: Cambridge, MA, USA, 1982.

147. Anderson, D.G. Models of Paleoindian and Early Archaic settlement in the lower Southeast. In The Paleoindian and Early Archaic Southeast; Anderson, D.G., Sassaman, K., Eds.; University of Alabama Press: Tuscaloosa, AL, USA, 1996; pp. 29-57.

148. Anderson, D.G.; Smallwood, A.M.; Miller, D.S. Pleistocene human settlement in the southeastern United States: Current evidence and future directions. PaleoAmerica 2015, 1, 7-51. [CrossRef]

149. Eren, M.I.; Buchanan, B.; O’Brien, M.J. Social learning and technological evolution during Clovis colonization of the New World. J. Hum. Evol. 2015, 80, 159-170. [CrossRef]

150. Eren, M.I.; Chao, A.; Chiu, C.; Colwell, R.K.; Buchanan, B.; Boulanger, M.T.; Darwent, J.; O’Brien, M.J. Statistical analysis of paradigmatic class richness supports greater Paleoindian projectile-point diversity in the Southeast. Am. Antiq. 2016, 81, 174-192. [CrossRef]

151. Hamilton, M.J.; Buchanan, B. The accumulation of stochastic copying errors causes drift in culturally transmitted technologies: Quantifying Clovis evolutionary dynamics. J. Anthropol. Archaeol. 2009, 28, 55-69. [CrossRef]

152. Stout, D. Stone toolmaking and the evolution of human culture and cognition. Philos. Trans. R. Soc. B 2011, 366, 1050-1059. [CrossRef] [PubMed]

153. Ellis, C.; Payne, J. Estimating failure rates in fluting based on archaeological data: Examples from NE North America. J. Field Archaeol. 1995, 22, 459-474.

154. Smallwood, A.M. Clovis biface technology at the Topper site, South Carolina: Evidence for variation and technological flexibility. J. Archaeol. Sci. 2010, 37, 2413-2425. [CrossRef]

155. Gardner, W.M. Flint Run Paleoindian complex and its implications for eastern North American prehistory. Ann. N. Y. Acad. Sci. 1977, 288, 257-263. [CrossRef]

156. Goodyear, A.C. A Hypothesis for the Use of Cryptocrystalline Raw Materials among Paleoindian Groups of North America; South Carolina Institute of Archeology and Anthropology, Research Manuscript Series, no. 6; University of South Carolina: Columbia, SC, USA, 1979.

157. Miller, D.S. Modeling Clovis landscape use and recovery bias in the southeastern United States using the Paleoindian Database of the Americas (PIDBA). Am. Antiq. 2016, 81, 697-716. [CrossRef]

158. Miller, G.L.; Bebber, M.R.; Rutkoski, A.; Haythorn, R.; Boulanger, M.T.; Buchanan, B.; Bush, J.; Lovejoy, C.O.; Eren, M.I. Hunter-gatherer gatherings: Stone-tool microwear from the Welling Site (33-Co-2), Ohio, U.S.A. supports Clovis use of outcrop-related base camps during the Pleistocene peopling of the Americas. World Archaeol. 2018. [CrossRef]

159. Buchanan, B.; O’Brien, M.J.; Collard, M. Continent-wide or region-specific? A geometric-morphometricsbased assessment of variation in Clovis point shape. Archaeol. Anthropol. Sci. 2014, 6, 145-162. [CrossRef]

160. Buchanan, B.; Hamilton, M.J. A formal test of the origin of variation in North American Early Paleoindian projectile points. Am. Antiq. 2009, 74, 279-298. [CrossRef]

161. Chapdelaine, C. (Ed.) Late Pleistocene Archaeology and Ecology in the Far Northeast; Texas A\&M University Press: College Station, TX, USA, 2012.

162. Richard, P.J.H.; Occhietti, S. 14C chronology for ice retreat and inception of Champlain Sea in the St. Lawrence Lowlands, Canada. Quat. Res. 2005, 63, 353-358. [CrossRef]

163. O’Brien, M.J.; Boulanger, M.T.; Buchanan, B.; Bentley, R.A.; Lyman, R.L.; Lipo, C.P.; Madsen, M.E.; Eren, M.I. Design space and cultural transmission: Case studies from Paleoindian North America. J. Archaeol. Method Theory 2016, 23, 692-740. [CrossRef]

164. Boyd, R.; Richerson, P.J. Culture and the Evolutionary Process; University of Chicago Press: Chicago, IL, USA, 1985. 
165. O'Brien, M.J.; Buchanan, B. Cultural learning and the Clovis colonization of North America. Evol. Anthropol. 2017, 26, 270-284. [CrossRef]

166. Gingerich, A.M.; Sholts, S.B.; Wärmländer, S.K.T.S.; Stanford, D. Fluted point manufacture in eastern North America: An assessment of form and technology using traditional metrics and 3D morphometrics. World Archaeol. 2014, 46, 101-122. [CrossRef]

167. Willerslev, E.; Davison, J.; Moora, M.; Zobel, M.; Coissac, E.; Edwards, M.E.; Lorenzen, E.D.; Vestergård, M.; Gussarova, G.; Haile, J.; et al. Fifty thousand years of arctic vegetation and megafaunal diet. Nature 2014, 506, 47-51. [CrossRef] [PubMed]

168. Wooler, M.J.; Saulnier-Talbot, E.; Potter, B.A.; Belmecheri, S.; Bigelow, N.; Choy, K.; Cwynar, L.C.; Davies, K.; Graham, R.W.; Kurek, J.; et al. A new terrestrial palaeoenvironmental record from the Bering Land Bridge and context for human dispersal. R. Soc. Open Sci. 2018. [CrossRef] [PubMed]

169. Dillehay, T.D.; Ocampo, C.; Saavedra, J.; Sawakuchi, A.O.; Vega, R.M.; Pino, M.; Collins, M.B.; Cummings, L.S.; Arregui, I.; Villagran, X.S.; et al. New archaeological evidence for an early human presence at Monte Verde, Chile. PLoS ONE 2015, 10, e0141923.

170. Dillehay, T.D.; Ramíriz, C.; Pino, M.; Collins, M.B.; Rossen, J.; Pino-Navarro, J.D. Monte Verde: Seaweed, food, medicine, and the peopling of South America. Science 2008, 320, 784-786. [CrossRef] [PubMed]

171. Kelly, R.L.; Todd, L.C. Coming into the country: Early Paleoindian hunting and mobility. Am. Antiq. 1988, 53, 231-244. [CrossRef]

(C) 2018 by the author. Licensee MDPI, Basel, Switzerland. This article is an open access article distributed under the terms and conditions of the Creative Commons Attribution (CC BY) license (http:/ / creativecommons.org/licenses/by/4.0/). 